\title{
New Technologies in Assessment and Neuropsychological Rehabilitation
}

\author{
Helenice Charchat Fichman ${ }^{1 *}$ \\ Emmy Uehara \\ Conceição Fernandes dos Santos \\ Departamento de Psicologia da Pontifícia Universidade Católica do Rio de Janeiro, \\ Rio de Janeiro, Brasil
}

\begin{abstract}
There is increasing use of technological innovations in assessment and neuropsychological rehabilitation in research and clinical practice. Thus, the purpose of this narrative review is to present what and how new technologies has been historically embedded in clinical and experimental neuropsychology, with a demonstrated academic production increased in the last 10 years. The literature presents that neuropsychological assessment highlights the use of computerized versions of instruments which traditionally are used in pencil and paper; cognitive simulations, artificial intelligence, and problem solving tasks. However, computerized tests are the most established technologies in this field. Further, a considerable part of the studies are performed in adults and elderly people, but few validations in children. In rehabilitation, the use of new technologies is more diversified, such as electronic devices and cell phones, tablet computers, video games, virtual reality, robots, and videofeedback neurofeedba$\mathrm{ck}$, transcranial direct current stimulation, among others. In neuropsychological rehabilitation, the new technologies have facilitated the development of compensatory strategies and real-world simulations. From this review we discuss the new possibilities of technological interfaces in neuropsychology, as well the need for development and validation of computerized batteries and more dynamic and versatile rehabilitation protocols.
\end{abstract}

Keywords: Neuropsychological assessment, neuropsychological rehabilitation; technologies.

\section{Novas Tecnologias na Avaliação e Reabilitação Neuropsicológica}

\section{Resumo}

Nas últimas décadas, observa-se um crescente uso de inovações tecnológicas na avaliação e reabilitação neuropsicológica em pesquisas e na prática clínica. Sendo assim, o objetivo da presente revisão narrativa é apresentar quais são e como as novas tecnologias vem sendo inseridas historicamente na neuropsicologia clínica e experimental, com um aumento da produção acadêmica evidenciada nos últimos 10 anos. A literatura evidencia que a avaliação neuropsicológica destaca o uso de versões computadorizadas de instrumentos, que tradicionalmente utilizavam o lápis e papel; simulações cognitivas; inteligência artificial; e tarefas de resolução de problemas. Contudo, a que se mostra mais consolidada é o uso de baterias de testes computadorizados. Além disso, uma parte considerável de estudos é feito com adultos e idosos,

1 Mailing address: Rua Marquês de São Vicente, 225, Edifício Cardeal Leme, sala 201, Gávea, Rio de Janeiro, RJ, Brasil 22453-900. E-mail: hcharchat@uol.com.br, emmy.uehara@gmail.com and conceicaosf@yahoo. com.br 
sendo as validações para crianças mais escassas. Na reabilitação, o uso de inovações tecnológicas se mostra mais diversificado, tais como a utilização de dispositivos eletrônicos e celulares, computadores e tablets, videogames, realidade virtual, robôs, videofeedback e neurofeedback, estimulação transcraniana por corrente contínua e direta, entre outros. Na reabilitação neuropsicológica, as novas tecnologias têm facilitado o desenvolvimento de estratégias compensatórias e simulações de situações do cotidiano. A partir desta revisão discute-se sobre as novas possibilidades das interfaces tecnológicas na neuropsicologia bem como a necessidade do desenvolvimento e validação de baterias computadorizadas e protocolos de reabilitação mais dinâmicos e versáteis.

Palavras-chave: Avaliação neuropsicológica, reabilitação neuropsicológica, tecnologias.

\section{Las Nuevas Tecnologías en la Rehabilitación Neuropsicológica y Evaluación}

\section{Resumen}

En las últimas décadas, hay un uso creciente de las innovaciones tecnológicas en la evaluación y rehabilitación neuropsicológica en la práctica clínica y la investigación. Por lo tanto, el propósito de esta revisión narrativa es presentar qué y cómo las nuevas tecnologías se han incorporado históricamente en neuropsicología clínica y experimental, con una producción académica demostrada aumentado en los ultimos 10 años. La literatura muestra que o más consolidado es el uso de baterías de pruebas computarizadas. Además, una parte considerable de los estudios se realizan con los adultos y ancianos, y con los ninos una validacion escasa. En la rehabilitación, la utilización de innovaciones tecnológicas se muestra más diversificada. Los estudios apuntan a utilizar: los dispositivos electrónicos y teléfonos celulares, y computadoras tablet, videojuegos, realidad virtual, robots y neurofeedback videofeedback, estimulación transcraneal de corriente continua y directa, entre otros. En la rehabilitación neuropsicológica, las nuevas tecnologías han facilitado el desarrollo de estrategias de compensación, simulaciones de situaciones reales. De esta revisión se discute que otros estudios deben llevarse a cabo para el desarrollo y validación de constructo de las baterías computarizadas y protocolos de rehabilitación que utilizan las nuevas tecnologías de tratamiento de la información y la comunicación

Palabras clave: Evaluación neuropsicológica, rehabilitación neuropsicológica, las tecnologias.

Function-related changes in cognition pertain to many neurological, psychiatric disorders and medical conditions (Capovilla, 2006), such as Autism (Billard, Robins, Nadel, \& Dautenhahn, 2007), Attention Deficit Hyperactivity Disorder (ADHD; Coutinho, Mattos, Araújo, \& Duchesne, 2007), Schizophrenia (Ritsner, Blumenkrantz, Dubinsky, \& Dwolatzky, 2006), Dementia (Hammers et al., 2012) and Hashimoto's Encephalopathy (Brooks \& Barlow, 2011). These changes can be seen through cognitionbased assessment protocols. By defining a cognitive profile, it is possible to make and create diagnostic assumptions that will lead to the indication of therapies (Lezak, 1995; Weintraub, 2000). One of these interventions is a rehabilita- tion program, aiming at the recovery of the impaired functions or their compensation (Fuentes, Malloy-Diniz, Camargo, \& Consenza, 2007; Rufo-Campos, 2006).

In terms of assessment and neuropsychological rehabilitation, traditionally, paper and pencil tasks and batteries are used in cognitive evaluation. However, in the last decades, protocols involving new technologies both in researches and clinical practices have emerged (Gonzalez et al., 2003; Horesh, 2001). These new technologies use computers, internet, smartphones, tablets, videogames and virtual reality.

According to Soto-Pérez, Martín, Angel, and Jiménez Gómez (2010), historically, cognitive neuropsychology is a branch of psychology 
that has always been influenced by cognitive sciences and by the information processing theories, artificial intelligence and, most recently, neural networks. These computer models stand out in the beginning of cognitive neuropsychology, where technological advances led to its main scientific findings.

The purpose of this literature review is to show which are and how technological innovations are being historically inserted into clinical and experimental neuropsychology. Review papers, development studies and clinical validation of the introduction of these new technologies into the context of assessment and neuropsychological rehabilitation will be presented.

\section{Methodology}

The paper is a historical and narrative review of the literature regarding innovation and technology in clinical neuropsychology. As search strategy, the issue was investigated in the following literature from the past 10 years: "PubMed", PsycInfo" and "Scielo". In addition, we have added to the search classic authors and studies pertaining to the validation of instruments that were used as basis for current tools. Following the selection of papers, two themes were defined: (a) assessment and (b) rehabilitation. The main technological innovations of neuropsychology were mentioned and described in these categories.

\section{Neuropsychological Assessment and the Use of New Technologies}

Literature shows how neuropsychological assessment strives to follow technological advances (Joly, Martins, Abreu, Souza, \& Cozza, 2004). Joly et al. (2004) point out: the use of computer versions of tools that, traditionally, used pencil and paper; cognitive simulation; artificial intelligence; and problem-solving tasks. Recently, other studies shows: (a) the internet and videoconferencing as possibilities in the neuropsychological assessment process (Bernardo-Ramos, Franco-Martíns, \& Soto-Pérez, 2012); (b) interactive voice response systems, with phone and computer cognition tests (D. I.
Miller, Talbot, Gagnon, \& Messier, 2013); (c) as well as virtual reality, such as Virtual Reality Lateralized Attention Test -VRLAT (Buxbaum, Dawson, \& Linsley, 2012), used to assess hemispatial neglect through virtually simulated real life situations based on attention demands.

Computer test batteries stand out and are largely consolidated in literature. Many advantages and some limitations are specifically found in regards to the use of these tests. Some of the advantages are:

1. Computer tests help standardizing the specifications for stimuli presentation and the gathering of responses, leading to a more severe control of the assessment conditions, which leads to greater psychometric reliability (Capovilla, 2006; Conklin et al., 2013; Ritsner et al., 2006; P. Schatz \& Browndyke, 2002);

2. Another advantage refers to the size of the sample; authors such as Hervey, Greenfield and Gualtieri (2012) refers to the efficacy of computer test batteries and claim tradition tests (interview-related pencil and paper) hinder large-scale studies;

3. Quick and easy recording of latencies and response types (Askar et al., 2012; Brooks \& Sherman, 2012);

4. They enable the development of many forms of the same test; they reduce financial costs such as paper-related costs (CharchatFichman, Nitrini, Caramelli, \& Sameshima, 2000);

5. They reduce the examiner's subjectivity effects and enable automatic performance correction (Cernich, Brennana, Barker, \& Bleiberg, 2007; Charchat, Nitrini, Caramelli, \& Sameshima, 2001; Ritsner et al., 2006; P. Schatz \& Browndyke, 2002; Woo, 2008);

6. Greater accuracy in finding cognitive changes (Mattos, 1998; Wild, Howieson, Webbe, Seelye, \& Kaye, 2008). Specific and complex variants, such as reaction time (RT) in milliseconds stand out among these measures. According to Charchat et al. (2001), RT allows more accurate and detailed assessment of cognition, and it helps avoiding the learning effect, which allows reusing the 
test and better monitoring of any eventual changes. This way, computer tests would more accurately supply response time and processing speed measures (Coppel, 2011).

The following stand out among disadvantages: (a) poorly designed interaction interfaces; (b) decreased face to face interaction between the physician and the patient; (c) practical and technical limitations, such as: because it is automatic, the examiner cannot interrupt or stop the test; (d) the use of the mouse, the keyboard or touch screen systems for the participants' responses limits the participation of disabled people or with motor deficits; (e) most tests depend on sight, because the questions are presented on the computer screen, while many traditional tests can take place orally. For instance, by reading a list of words so that the patient can recall them later (Elwood, 2001; P. Schatz \& Browndyke, 2002).

Despite limitations, the advantages presented are quite significant. With these advantages, technology plays a more important role in the cognition, leading to early diagnosis and follow-up of the clinical evolution of many diseases (Charchat et al., 2001; Woo, 2008). In this sense, having adequate neuropsychological assessment tools is essential.

\section{Computer-Based Tests: Populations and Cognitive Functions Assessed}

Given the advantages and limitations of computer-based tests, these tests must be designed taking into account the inherent individual differences of the different target populations (P. Schatz \& Browndyke, 2002). A great deal of validations and studies regarding computerbased tests and batteries have involved adults and elderly and children-related validations are rare (Rohlman et al., 2008).

Batteries found for children emphasize attention tasks, such as response time and ongoing performance. Ongoing performance is assessed through omission errors (when the target stimulus is not found), persistence (in the case of im- pulsive response) and improper stimulus (when non-target stimulus is found). One of the most widely accepted tools to assess the attention behavior and ADHD diagnosis is the Continuous Performance Test (CPT; Bloch et al., 2012). It measures sustained and selective attention and impulsivity (Conners, 2002). Continuous performance tests can take place in many ways. In children, a very common test is The Test of Variables of Attention - TOVA (Bloch et al., 2012; Dupuy \& Greenberg, 1993). This model can also be used through more specific tasks, as shown by a 2012 study (Lufi \& Fichman, 2012). The authors built mathematic computer tasks with visual stimuli, referred to as Mathematics Continuous Performance Test (MATH-CPT). A. M. Schatz, Ballantyne, and Trauner (2001) points out this test model would be greatly useful and adequate to assess ADHD patients.

In Brazil, the main computer test validated for the assessment of children and teenagers is Tavis-III (Duchesne \& Mattos, 1997). This test battery assesses concentration, selective and alternant attention in three tasks. Coutinho et al. (2007) used Tavis-III to assess children and teenagers with and without ADHD. The authors worked with 102 participants diagnosed with ADHD, who were compared against 678 people from the control group. Analyses also showed the high specificity and sensibility of the test towards ADHD-diagnosed patients.

Recently, other studies involving children are directed at issues other than the Attention deficit hyperactivity disorder diagnoses. Brooks and Sherman (2012) present research data with patients sent to a neurology outpatient clinic with many different diagnoses, such as epilepsy and head injury, using the CNS VITAL SIGNS test battery. Another paper reports a case study with a 14-year old where cognitive monitoring and initial assessment take place with the same computer-based test battery (CNS VITAL SIGNS) for a Hashimoto's encephalopathy case (an autoimmune disease; Brooks \& Barlow, 2011). The significance of computer-based testing can also be seen in teenagers with brain tumors in face of the secondary cognitive impact. Conklin and others (2013) use Impact, a computer- 
based battery that tests attention, memory and processing speed. Still in this context, CANTAB studies, firstly designed for the elderly (Sahakian \& Owen, 1992), have shown their potential to assess executive functions in children (Fried, Hirshfeld-Becker, Petty, Batchelder, \& Biederman, 2012; Luciana, 2003).

As for the elderly, computer-based tests have been designed and used to assess cognitive impairment and the effect of medications (Caramelli et al., 2004; Charchat et al., 2001; Powell, Kaplan, Whitla, Catlin, \& Funkenstein, 1993; Tornatore, Hill, Laboff, \& McGann, 2005).

Wild and others (2008) identified 11 computer-based test batteries to assess the elderly, including MCI and dementia, such as: Microcog (Powell et al., 1993); MCI Screen, CANS-MCI (Tornatore etal., 2005); a Cognitive Stability Index - CSI (Erlanger et al., 2002) variance to screen and monitor changes; CNTB (Computerized Neuropsychological Test Battery); Mindstreans (Dwolatzky et al., 2003); the CNSVS battery, CNS Vital Signs (Gualtieri \& Johnson, 2006); CogState; COGDRAS (Cognitive Drug Research Computerized Assessment System; Simpson, Surmon, Wesnes, \& Wilcock, 1991), which has not been specifically designed to be used with the elderly, but is being adjusted to be used with patients suffering from dementia, as well as the ANAM (Automated Neuropsychological Assessment Metrics; Reeves, Winter, Bleiberg, \& Kane, 2007).

Most of these tests surveyed by Wild and others (2008) are still being used, and its use has been increasing among many populations, such as, for instance, Cogstate (Hammers et al., 2012), used to screen dementia and mild cognitive impairment; and ANAM. The reliability of ANAM with patients with Parkinson has been recently validated (Hawkins et al., 2012), with varying statistical reliability in sub-tests to assess that population, yet effective. In Brazil, CompCog, designed by the cognitive neurology and behavior at University of São Paulo (USP), is highly sensitive and specific for the early diagnosis of Alzheimer's (Charchat et al., 2001).

In adults, the main evidences found in literature are clinical validations of the computer- based tests for psychiatric disorders and HIVrelated cognitive declined. Test batteries such as Mindstream (Ritsner et al., 2006) and IntegNeuro (Williams et al., 2008) are sensitive and are used to find cognitive deficits in patients suffering from schizophrenia. Tests such as the Groton Maze Learning Test - GLMT (Pietrzak et al., 2008), CalCAP (Gonzalez et al., 2003), CogState (Overton et al., 2011) and Microcog (Fama, Rosenbloom, Nichols, Pfefferbaum, \& Sullivan, 2009) are effective in HIV-related studies.

Ritsner et al. (2006) noticed that patients suffering from schizophrenia performed worse than the healthy control group in the Mindstream. Williams and others (2008) show the efficacy of IntegNeuro in the first episode of schizophrenia. Studies with HIV positive patients also take place through response time battery tests, such as CalCAP (Gonzalez et al., 2003). In this study, mild specificity (77\%) and sensitiveness (68\%) were found to assess cognitive impairment in HIV patients compared to traditional tests. But studies with battery tests such as CogState (Overton et al., 2011) and Microcog (Fama et al., 2009) are also found.

Figure 1 shows the description of the tests, computerization of paper and pencil in tests most commonly found across literature and mentioned in this section, representing tests used in aging pathologies and psychiatric disorders in children, teenagers or adults

\section{Neuropsychological Rehabilitation and New Technologies}

Neuropsychological rehabilitation is a broad, interactive and two-way approach where the patient is an active agent in this process. The physical, psychological, social and professional well-being of the patient is the aim of the joint work of team professionals, family, society members and the patient at issue (McLellan, 1991). According to the World Health Organization (WHO, 1980), rehabilitation is aimed at reducing the impact of disability and disabling conditions, thus enabling disabled people to ideally take part in the society. For Wilson (1996), neuropsychological rehabilitation enables treat- 


\begin{tabular}{|c|c|c|c|}
\hline ANAM (Reeves et al., 2007) & \multicolumn{3}{|c|}{ Battery used to assess the accuracy and attention speed, memory and thought. } \\
\hline $\begin{array}{l}\text { BTNC (Charchat, 1999) } \\
\text { and CompCog } \\
\text { (Charchat et al., 2001) }\end{array}$ & \multicolumn{3}{|c|}{$\begin{array}{l}\text { Six neuropsychological tests have been designed to assess primary memory, } \\
\text { short-term memory, response time and implicit learning. The tests involve } \\
\text { simple response time tests, choice response time, implicit learning, short-term } \\
\text { word learning, short-term picture learning and short-term face learning. } \\
\text { A brief battery referred to as CompCog was designed for the early diagnosis } \\
\text { of Alzheimer's, including response time and remembering faces as cognitive } \\
\text { markers. }\end{array}$} \\
\hline $\begin{array}{l}\text { CANTAB } \\
\text { (Fray, Robbins, \& Sahakian, 1996; } \\
\text { Wild et al., 2008) }\end{array}$ & \multicolumn{3}{|c|}{$\begin{array}{l}\text { The battery includes: work memory and executive functions; visual and spatial } \\
\text { memory, attention and response time; verbal memory and decision-making } \\
\text { processes. These are assessed through } 13 \text { tests. It was firstly designed to } \\
\text { diagnose dementia. }\end{array}$} \\
\hline $\begin{array}{l}\text { CNS Vital Signs } \\
\text { (Gualtieri \& Johnson, 2006; Wild } \\
\text { et al., 2008) }\end{array}$ & \multicolumn{3}{|c|}{$\begin{array}{l}\text { This test includes seven tests involving: memory, psychomotor speed, response } \\
\text { time, cognitive flexibility and complex attention. }\end{array}$} \\
\hline $\begin{array}{l}\text { CNTB } \\
\text { (Cutler et al., 1993; } \\
\text { Wild et al., 2008) }\end{array}$ & \multicolumn{3}{|c|}{$\begin{array}{l}\text { This battery is comprised of } 11 \text { subtests that assess motor speed, information } \\
\text { processing, attention, verbal and spatial memory, language and spatial skills. } \\
\text { The Computerized Neuropsychological Test Battery (CNTB) is one of the first } \\
\text { attempts to test cognitive functions in a computer. }\end{array}$} \\
\hline $\begin{array}{l}\text { Continuous Performance Test } \\
\text { (Conners, 2002) }\end{array}$ & $\begin{array}{l}\text { It assesses sustained } \\
\text { and selective } \\
\text { attention and } \\
\text { impulsivity. }\end{array}$ & $\begin{array}{l}\text { Example 1: The Test of } \\
\text { Variables of Attention } \\
\text { - TOVA (Dupuy \& } \\
\text { Greenberg, 1993) }\end{array}$ & $\begin{array}{l}\text { Example 2: Mathematics } \\
\text { Continuous Performance } \\
\text { Test - MATH-CPT (Lufi } \\
\text { \& Fichman, 2012) }\end{array}$ \\
\hline $\begin{array}{l}\text { COGDRAS-D (Simpson et al., } \\
\text { 1991, Wild et al., 2008) }\end{array}$ & \multicolumn{3}{|c|}{$\begin{array}{l}\text { Battery designed to assess positive and negative effects of drugs over cognition. } \\
\text { Adjusted to be used with dementia. The battery includes eight subtests. }\end{array}$} \\
\hline $\begin{array}{l}\text { CogState (Hammers et al., 2012; } \\
\text { Wild et al, 2008) }\end{array}$ & \multicolumn{3}{|c|}{$\begin{array}{l}\text { Subtests include simple, choice and complex response time, continuous } \\
\text { monitoring, work memory, relationships, incidental and associative learning. }\end{array}$} \\
\hline $\begin{array}{l}\text { Cognitive Stability Index -CSI } \\
\text { (Erlanger et al., 2002; Wild et al., } \\
\text { 2008) }\end{array}$ & \multicolumn{3}{|c|}{$\begin{array}{l}\text { It includes four components (memory, attention, response speed and processing } \\
\text { speed) based on } 10 \text { subtests. Authors suggest the Cognitive Stability Index } \\
\text { (CSI) to screen and monitor changes. }\end{array}$} \\
\hline MCIS (Wild et al., 2008) & \multicolumn{3}{|c|}{ Computer-based version of the CERAD word list task. } \\
\hline $\begin{array}{l}\text { MicroCog } \\
\text { (Powell et al., 1993) }\end{array}$ & \multicolumn{3}{|c|}{$\begin{array}{l}\text { One of the first commercially developed computer-based batteries to detect } \\
\text { early signs of cognitive impairment. It assesses memory, attention, response } \\
\text { time, skills, visual and spatial thinking and calculation skills. }\end{array}$} \\
\hline $\begin{array}{l}\text { Mindstreams } \\
\text { (Ritsner et al., 2006; } \\
\text { Wild et al., 2008) }\end{array}$ & \multicolumn{3}{|c|}{$\begin{array}{l}\text { Designed to detect MCI. This battery is comprised of } 9 \text { subtests: verbal memory, } \\
\text { non-verbal memory, response inhibition, Stroop interference, problem solving, } \\
\text { visual and spatial images, verbal rhymes, naming, processing speed and visual } \\
\text { and motor planning. Many of these tests are paper and pencil adaptations. }\end{array}$} \\
\hline $\begin{array}{l}\text { CalCAP (E. N. Miller, 1996; E. N. } \\
\text { Miller, Satz, \& Visscher, 1991) }\end{array}$ & \multicolumn{3}{|c|}{ Response time per choice - Digits and sequential response Time. } \\
\hline $\begin{array}{l}\text { Groton Maze Learning } \\
\text { Test -GLMT } \\
\text { (Pietrzak et al., 2008) }\end{array}$ & \multicolumn{3}{|c|}{$\begin{array}{l}\text { Groton Maze Learning Test (GMLT) is a recent computer-based } \\
\text { neuropsychological measure that assesses short-term, primary memory } \\
\text { and visual and spatial information. It is also sensitive to finding errors and } \\
\text { persistence and delay in the processing of information in healthy adults. }\end{array}$} \\
\hline $\begin{array}{l}\text { IntegNeuro } \\
\text { (Williams et al., 2008) }\end{array}$ & \multicolumn{3}{|c|}{$\begin{array}{l}\text { It assesses motor function, attention, learning and memory, fluency, executive } \\
\text { function and estimated intelligence. }\end{array}$} \\
\hline $\begin{array}{l}\text { TAVIS-III } \\
\text { (Duchesne \& Mattos, 1997) }\end{array}$ & \multicolumn{3}{|c|}{$\begin{array}{l}\text { It assesses the concentration, selective skills and selective attention in three } \\
\text { tasks. }\end{array}$} \\
\hline
\end{tabular}

Figure 1. Brief description of computer-based tests and batteries. 
ing emotional, behavioral, personality and motor impairments, as well as the patient's cognitive deficits. That is, it brings functional adaptability and environmental integration to the patient (Abrisqueta-Gomez, 2006).

Despite the improper use of the expression "neuropsychological rehabilitation" as a synonym for "cognitive rehabilitation", Prigatano (1997) points out cognitive rehabilitation is only one of the five neuropsychological rehabilitation components, which would also include psychotherapy, the definition of a therapeutic environment, psychoeducation and the work with family members and the patient. This way, according to Wilson (1996), cognitive rehabilitation will enable patients and family members to live with, deal with, reduce or overcome cognitive impairments arising from neurological lesions, such as linguistic, perceptual, attention, memory, executive and praxic impairments.

Zangwill (1947) and, later, Prigatano (1986) found three training approaches for the cognitive rehabilitation: (a) compensation; (b) replacement; and (c) direct retraining. In general, compensation approach involves implementing strategies and resources that enable the patient to deal with or avoid the impairment. Through replacement, it is possible to incorporate alternate systems to perform tasks usually mediated by the affected systems. And, finally, direct retraining relates to the specific train of impaired cognitive functions. Prigatano (1986) also defends a fourth approach, using each one of these principles, which would lead to the recovery of the cognition.

Similarly, Sohlberg e Mateer (1989) distinguish rehabilitation in three basic approaches: (a) general stimulus - use of cognitive training materials without specific theoretical guidance; (b) functional adaptation - retraining takes place in the functional context of ecologic daily life and work situations; and (c) specific process based on cognitive theoretical models, a series of training tasks is provided, hierarchically organized and aimed at specific components of cognitive processes. Still, the authors describe some essential principles pertaining to cognitive rehabilitation, such as, for instance, a theoretically guided model, repetitive tasks, hierarchical organization of tasks and directed treatment.

To reach these goals, cognitive rehabilitation uses compensation techniques and cognitive strategies such as cognitive stimulation, training and exercises in an attempt to reduce the problems faced by the patient on a daily basis. With the advance of technologies, other resources and devices have been used in rehabilitation, providing new alternatives for old practices.

The use of technology in neuropsychological researches and clinical practices takes place through many different ways, mediated by the internet or not: electronic devices and smartphones (Svoboda \& Richards, 2009), computers and tablets (Stuifbergen et al., 2012), videogames (Belchior et al., 2013), virtual and augmented reality (Bohil, Alicea, \& Biocca, 2011), robots (Billard et al., 2007), video feedback and neurofeedback (Soekadar, Birbaumer, \& Cohen, 2011), transcranial direct current stimulation (Kang, Kim, \& Paik, 2012), among many others. Next, some possibilities for the use of technology in the rehabilitation process will be discussed and exemplified.

Many daily electronic pieces of equipment are used, in special, in attention, memory and executive functions rehabilitation. Alarm clocks, timers, pagers, cameras, voice recorders, fixed and mobile phones, computers, tablets, PCs, smartphones applications and web 2.0 technology resources are powerful tools in the application of some compensation techniques. These technological resources enable the user to perform daily tasks with greater autonomy and improve the patient's and family members' life quality (Inglis et al., 2004).

In addition, these devices can be used as organization and monitoring tools in patients suffering from executive deficits, providing todo lists and daily and weekly plans, as well as acting as external, auxiliary memory, helping the patients not to forget appointments or helping patients with prospective memory impairment not to forget their meds. Wilson, Evans, Emslie and Malinek (1997), for instance, report the 
most common messages made available by this system are "good morning, today is the $X$, date $Y$ ", "don't forget your meds" and "please insert your appointments". These messages helps elderly people that shows mnemonic damages in daily tasks. However, not all elderly people are familiar with the technology employed in some devices such as computers or smartphones. In this case, it would be better to use simpler devices, such as clocks or voice recorders. For patients who are more familiar with technology, applications for computers, smartphones or tablets are available, helping, for instance, to remember, to organize (Astrid Tasks/To-do List ${ }^{\circledR}$ ) and to file information (Evernote $\left.{ }^{\circledR}\right)$, to manage time, money and medications (Pillboxie ${ }^{\circledR}$ ), to get dressed (iDress for weather ${ }^{\circledR}$ ) and to store passwords (Keeper Password \& Data Vault $\AA$ ). All of them can be used together with other electronic devices with the same system and shared and monitored by other people.

Linked to a young culture, current videogames are for all, regardless of gender and age. More and more modern and versatile, computer games and videogames are quite known and widespread in the health branch, says Kato (2010). Treatments related to distraction and management of the pain in patients suffering from burns and the use to encourage boring, repetitive occupational therapy tasks are some common uses (Griffiths, 2005). Innovations found in computer games and videogames have disseminated the use of new equipment, such as, for instance, Nintendo ${ }^{\circledR}$ Wii videogame console, the Dance Dance Revolution (DDR) ${ }^{\circledR}$ dance platform and the Kinect Xbox ${ }^{\circledR}$ motion sense input device. Besides being interactive, intuitive and easy to use, they are pleasant to all ages.

Despite the negative media trend to link videogames to greater violence and obesity risks, researchers have investigated the advantages of games and its elements (Rivero, Querino, \& Starling-Alves, 2012). If they were merely seen as entertainment in the past, today videogames are used as specific rehabilitation training tools and cognitive skill changing tools, such as visual perception, motor skills, attention and decision- making processes (Boot, Kramer, Simons, Fabiani, \& Gratton, 2008; Green \& Bavelier, 2003; Nouchi et al., 2012). In view of advances in researches and deeper knowledge regarding videogame, new uses arise. Different studies are being performed in terms of work memory in children with Attention Deficit Hyperactivity Disorder - ADHD (Gray et al., 2012), for autistic individuals to work on facial recognition (Tanaka et al., 2010) and to improve the self-esteem and well being of the elderly (Gamberini, Alcaniz, et al., 2008). For instance, Tanaka and others (2012) have designed a battery of emotional skills named Let's Face It! with 3 subtests related to the relationship between the name of the emotion and the image, combination of facial expressions and recognition of face parts.

According to Gamberini, Barresi, Majer and Scarpetta, (2008) and Kellar, Watters and Duffy (2005), computer games and videogames are funny and encouraging, are aesthetically attractive, provide immediate action feedback, can adjust to the person's level and ensure actions are repeated until they become automatic. All these factors are essential for the patient to engage in the rehabilitation.

Another technology that has been increasing is virtual reality (VR). Although VR systems are new in neuropsychology, they were widely used in professional training programs, such as flight simulators. VR interfaces enable safe training, in special in situations when real practice would be dangerous, expensive or it would be difficult to monitor or control the task to be performed, as it happens with firefighters, divers, skydivers or even surgeons (Rose, Brooks, \& Rizzo, 2005). This way, this technology allows users to interact in a three-dimension scenario through computer techniques and equipment such as headphones, head-mounted displays and eyeglasses and handhelds, recreating the feeling of reality - even if temporary. One of the most important elements for the involvement in this virtual world is the immersion feeling. With interfaces or devices that augment the sensory input, cognitive and perceptive systems lead one to believe he is in a different place than where 
he physically is. That is, the body experiences the sensation of being inserted into the scene (Freeman et al., 2006).

By creating realistic, dynamic and embracing scenarios, VR has offered new experiences in some diseases, providing grounds for the monitoring and training of the individual's behavioral responses. Virtual environments working with specific mental or motor-related impairments, as shown in posttraumatic stress disorder (PTSD), panic and phobias (Botella et al., 2007), Parkinson's (Ma et al., 2011), intellectual impairment (Pérez-Salas, 2008), autism (Parsons $\&$ Cobb, 2011) and ADHD (Pollak et al., 2009). One of the advantages of this technology is the reduction in the difference between the laboratory environment and a real situation. This way, the treatment can employ the virtual interface regardless of the challenges or fears, since the tasks can be gradually made more complex. The motivational factor must also be taken into account. As it is a new technology, ignorance or unawareness can be common in this virtual environment, which can lead to greater interest and curiosity.

Augmented reality (AR) has also aided in the assessment and rehabilitation process by providing unique techniques, still not found in traditional neuropsychological methods (Rizzo et al., 2000). Some AR uses have been developed aimed at cognitive processes, including attention processes, spatial skills, memory and executive functions (Grealy, Johnson, \& Rushton, 1999; Pugnetti et al., 1998). For instance, in children with $\mathrm{ADHD}$, it is possible to assess and train attention focus at virtual classrooms and without distractions (Rizzo et al., 2000). Similarly, these virtual environments can help in the functional training of instrumental activities of daily living (IADL). In these environments, the patient can practice how to cook meals, how to recognize common objects, how to simulate purchases or practice how to use public transportation in a greener way (Rose et al., 2005).

\section{Conclusion}

The use differences of new technologies in the neuropsychological assessment and rehabilitation precisely lie on their advantages and limitations (Charchat-Fichman et al., 2000). The most evident advantage in neuropsychological assessment is timely control in the introduction of stimuli, recording latency and duration of responses in milliseconds (Soto-Pérez et al., 2010). This advantage enables recording the response time and the information processing speed with greater accuracy than traditional tests employing paper and pencil (Charchat-Fichman et al., 2000; Kay \& Starbuck, 1997). In rehabilitation, the new technologies have enabled the development of compensation strategies and the simulation of daily life situations, leading to greener training procedures (Rizzo et al., 2000).

Main limitations refer to the need to monitor the patient's interaction with the new technologies to procure qualitative data and to find any comprehension difficulties and preserving instructions in the work memory (CharchatFichman et al., 2000; Kay \& Starbuck, 1997). Another problem found is resistance and anxiety in view of innovation generated by these technologies, and this limitation is the main challenge for the next years, in special for the elderly (Browndyke et al., 2002). The implicit training of new methodologies and the use of more intuitive novelties, such as touchscreen and tablets, can reduce resistance (Ott et al., 2008).

Despite the increasing use of new technologies in rehabilitation, in special videogames and augmented reality, there are very few empirical studies regarding the efficacy and power of generalization of these strategies in the daily lives of patients (Rivero et al., 2012). New studies must be performed for the development and validation of computer-based batteries and rehabilitation protocols employing new information processing technologies and communication. Cultural adjustments, considering education, socioeconomic level and age must be included in the validation studies of computer-based paradigms. 


\section{References}

Abrisqueta-Gomez, J. (2006). Reabilitação neuropsicológica: "O caminho das pedras". In J. Abrisqueta-Gomez \& F. H dos Santos (Eds.), Reabilitação neuropsicológica: Da teoria à prática (pp. 1-14). São Paulo, SP: Artes Médicas.

Askar, P., Altun, A., Cangöz, B., Çevik, V., Kaya, G., \& Türksoy, H. (2012). A Comparison of paper-and-pencil and computerized forms of line orientation and enhanced cued recall tests. Psychological Reports, 110(2), 383-396. doi:10.2466/03.22.PR0.110.2.383-396

Belchior, P., Marsiske, M., Sisco, S. M., Yam, A., Bavelier, D., Ball, K., \& Mann, W. C. (2013). Video game training to improve selective visual attention in older adults. Computers in Human Behavior, 29(4), 1318-1324. doi:10.1016/j. chb.2013.01.034

Bernardo-Ramos, M., Franco-Martín, M. A., \& SotoPérez, F. (2012). Cyber-neuropsychology: Application of new technologies in neuropsychology evaluation. Actas Españolas de Psiquiatria, 40(6), 308-314.

Billard, A., Robins, B., Nadel, J., \& Dautenhahn, K. (2007). Building robota, a mini-humanoid robot for the rehabilitation of children with autism. Assistive Technology, 19(1), 37-49.

Bloch, Y., Fixman, M., Maoz, H., Bloch, A. M., Levkovitz, Y., Ratzoni, G., ...Gal, G. (2012). Can computerized cognitive tests assist in the clinical diagnosis of attention-deficit hyperactivity disorder? The Journal of Neuropsychiatry and Clinical Neurosciences, 24(1), 111-114. doi:10.1176/appi.neuropsych.11010014

Bohil, C. J., Alicea, B., \& Biocca, F. A. (2011). Virtual reality in neuroscience research and therapy. Nature Reviews Neuroscience, 12(12), 752-762. doi:10.1038/nrn3122

Boot, W. R., Kramer, A. F., Simons, D. J., Fabiani, M., \& Gratton, G. (2008). The effects of video game playing on attention, memory, and executive control. Acta Psychologica, 129(3), 387398. doi:10.1016/j.actpsy.2008.09.005

Botella, C., García-Palacios, A., Villa, H., Baños, R. M., Quero, S., Alcañiz, M., \& Riva, G. (2007). Virtual reality exposure in the treatment of panic disorder and agoraphobia: A controlled study. Clinical Psychology \& Psychotherapy, 14(3), 164-175. doi:10.1002/cpp.524
Brooks, B. L., \& Barlow, K. M. (2011). A methodology for assessing treatment response in Hashimoto's encephalopathy: A case study demonstrating repeated computerized neuropsychological testing. Journal of Child Neurology, 26(6), 786791. doi:10.1177/0883073810391532

Brooks, B. L., \& Sherman, E. M. (2012). Computerized neuropsychological testing to rapidly evaluate cognition in pediatric patients with neurologic disorders. Journal of Child Neurology, 27(8), 982-991. doi:10.1177/0883073811430863

Browndyke, J. N., Albert, A. L., Malone, W., Schatz, P., Paul, R. H., Cohen, R. A., ...Gouvier, W. D. (2002). Computer-related anxiety: Examining the impact of technology-specific affect on the performance of a computerized neuropsychological assessment measure. Applied Neuropsychology, 9(4), 210-218.

Buxbaum, L. J., Dawson, A. M., \& Linsley, D. (2012). Reliability and validity of the Virtual Reality Lateralized Attention Test in assessing hemispatial neglect in right-hemisphere stroke. Neuropsychology, 26(4), 430-441. doi:10.1037/ a0028674

Capovilla, A. G. S. (2006). Desenvolvimento e validação de instrumentos neuropsicológicos para avaliar funções executivas. Avaliação Psicológica, 5(2), 239-241.

Caramelli, P., Chaves, M. L., Engelhardt, E., Machado, J. C. B., Schultz, R. R., Vale, F. A., \& Charchat-Fichman, H. (2004). Effects of galantamine on attention and memory in Alzheimer's disease measured by computerized neuropsychological tests: Results of the Brazilian MultiCenter Galantamine Study (GAL-BRA-01). Arquivos de Neuro-Psiquiatria, 62(2B), 379-384. doi:10.1590/S0004-282X2004000300001

Cernich, A. N., Brennana, D. M., Barker, L. M., \& Bleiberg, J. (2007). Sources of error in computerized neuropsychological assessment. Archives of Clinical Neuropsychology, 22(Suppl. 1), S39S48. doi:10.1016/j.acn.2006.10.004

Charchat, H. (1999). Desenvolvimento de uma bateria de testes neuropsicológicos computadorizados para o diagnóstico precoce da Doença de Alzheimer (Dissertação de mestrado, Curso de Pós-Graduação de Neurociências e Comportamento, Instituto de Psicologia, Universidade de São Paulo, SP, Brasil). 
Charchat, H., Nitrini, R., Caramelli, P., \& Sameshima, K. (2001). Investigação de marcadores clínicos dos estágios iniciais da doença de Alzheimer com testes neuropsicológicos computadorizados. Psicologia: Reflexão e Crítica, 14(2), 305-316.

Charchat-Fichman, H., Nitrini, R., Caramelli, P., \& Sameshima, K. (2000). Contribuição da avaliação neuropsicológica computadorizada no diagnóstico da doença de Alzheimer. In M. de J. Gonçalves, E. C. de Macedo, A. L. Sennyey, \& F. C. Capovilla (Eds.), Tecnologia em (re) habilitação cognitiva (pp. 110-116). São Paulo, SP: Centro Universitário São Camilo.

Conklin, H. M., Ashford, J. M., Di Pinto, M., Vaughan, C. G., Gioia, G. A., Merchant, T. E., ...Wu, S. (2013). Computerized assessment of cognitive late effects among adolescent brain tumor survivors. Journal of Neuro-Oncology, 113(2), 333340. doi:10.1007/s11060-013-1123-5

Conners, C. K. (2002). Conners' continuous performance test. Toronto, Canada: Multi-Health System.

Coppel, D. B. (2011). Use of neuropsychological evaluations. Physical Medicine and Rehabilitation Clinics of North America, 22(4), 653. doi:10.1016/j.pmr

Coutinho, G., Mattos, P., Araújo, C., \& Duchesne, M. (2007). Transtorno do déficit de atenção e hiperatividade: Contribuição diagnóstica de avaliação computadorizada de atenção visual. Revista de Psiquiatria Clínica, 34(5), 215-222.

Cutler, N. R., Shrotriya, R. C., Sramek, J. J., Veroff, A. E., Seifert, R. D., Reich, L. A., \& Hironaka, D. Y. (1993). The use of the Computerized Neuropsychological Test Battery (CNTB) in an efficacy and safety trial of BMY 21,502 in Alzheimer's disease. Annals of the New York Academy of Sciences, 24(695), 332-336.

Duchesne, M., \& Mattos, P. (1997). Normatização de um teste computadorizado de atenção visual. $A r$ quivos de Neuropsiquiatria, 55(1), 62-69.

Dupuy, T. R., \& Greenberg, L. M. (1993). The T.O.V.A. manual for IBM personal computer or IBM compatible (Version 6.X). Minneapolis, $\mathrm{MN}$ : Greenberg.

Dwolatzky, T., Whitehead, V., Doniger, G. M., Simon, E. S., Schweiger, A., Jaffe, D., \& Chertkow, H. (2003). Validity of a novel computerized cognitive battery for mild cognitive impairment. $B M C$ Geriatrics, 3, 1-12. doi:10.1186/1471-2318-3-4
Elwood, T. W. (2001). Medicare's role in financing allied health clinical training. Journal of Allied Health, 30(3), 141-145.

Erlanger, D. M., Kaushik, T., Broshek, D., Freemand, J., Feldman, D., \& Festa, J. (2002). Developments and validations of a web-based screening tool for monitoring cognitive status. Journal of Head Trauma Rehabilitation, 17(5), 458-476. doi:10.1097/00001199-200210000-00007

Fama, R., Rosenbloom, M. J., Nichols, B. N., Pfefferbaum, A., \& Sullivan, E. V. (2009). Working and episodic memory in HIV infection, alcoholism, and their comorbidity: Baseline and 1-year follow-up examinations. Alcoholism: Clinical and Experimental Research, 33(10), 1815-1824. doi:10.1111/j.1530-0277.2009.01020.x

Fray, P. J., Robbins, T. W., \& Sahakian, B. J. (1996). Neuropsychiatric applications of CANTAB. International Journal of Geriatric Psychiatry, 11, 329-336.

Freeman, J., MacMillan, J., Haimson, C., Weil, S., Stacy, W., \& Diedrich, F. (2006). From gaming to training. Society for Advanced Learning Technology, 8-10.

Fried, R., Hirshfeld-Becker, D., Petty, C., Batchelder, H., \& Biederman, J. (2012). How Informative Is the CANTAB to assess executive functioning in children with ADHD? A controlled study. Journal of Attention Disorders. doi:10.1177/1087054712457038

Fuentes, D., Malloy-Diniz, L. F., Camargo, C. H. P., \& Cosenza R. M. (2007) Neuropsicologia: Teoria e prática. Porto Alegre, RS: Artmed.

Gamberini, L., Alcaniz, M., Barresi, G., Fabregat, M., Prontu, L., \& Seraglia, B. (2008). Playing for a real bonus: Videogames to empower elderly people. Journal of CyberTherapy \& Rehabilitation, 1(1), 37-48.

Gamberini, L., Barresi, G., Majer, A., \& Scarpetta, F. (2008). A game a day keeps the doctor away: A short review of computer games in mental healthcare. Journal of CyberTherapy and Rehabilitation, 1(2), 127-145.

Gonzalez, R., Heaton, R. K., Moore, D. J., Letendre, S., Ellis, R. J., Wolfson, T., ...Grant, I. (2003). Computerized reaction time battery versus a traditional neuropsychological battery: Detecting HIV-related impairments. Journal of the International Neuropsychological Society, 9, 64-71. doi:10.1017/S1355617703910071 
Gray, S. A., Chaban, P., Martinussen, R., Goldberg, R., Gotlieb, H., Kronitz, R., ...Tannock, R. (2012). Effects of a computerized working memory training program on working memory, attention, and academics in adolescents with severe LD and comorbid ADHD: A randomized controlled trial. Journal of Child Psychology and Psychiatry, 53(12), 1277-1284. doi:10.1111/ j.1469-7610.2012.02592.x

Grealy, M. A., Johnson, D. A., \& Rushton, S. K. (1999). Improving cognitive function after brain injury: The use of exercise and virtual reality. Archives of Physical Medicine and Rehabilitation, 80, 661-667. doi:10.1016/S00039993(99)90169-7

Green, C. S., \& Bavelier, D. (2003). Action video game modifies visual selective attention. Nature, 423(6939), 534-537. doi:10.1038/ nature01647

Griffiths, M. (2005). The therapeutic value of video games. In J. Raessens \& J. Goldstein (Eds.), Handbook of computer games studies (pp. 161171). Cambridge, MA: The Massachusetts Institute of Technology Press.

Gualtieri, C. T., \& Johnson, L. G. (2006). Reliability and validity of a computerized neurocognitive test battery, CNS Vital Signs. Archives of Clinical Neuropsychology, 21, 623-643.

Hammers, D., Spurgeon, E., Ryan, K., Persad, C., Barbas, N., Heidebrink, J., ...Giordani, B. (2012). Validity of a brief computerized cognitive screening test in dementia. Journal of Geriatric Psychiatry and Neurology, 25(2), 89-99. doi:10.1177/0891988712447894

Hawkins, K. A., Jennings, D., Vincent, A. S., Gilliland, K., West, A., \& Marek, K. (2012). Traditional neuropsychological correlates and reliability of the Automated Neuropsychological Assessment Metrics-4 battery for Parkinson's disease. Parkinsonism and Related Disorders, 18, 864870. doi:10.1016/j.parkreldis.2012.04.021

Hervey, A. S., Greenfield, K., \& Gualtieri, C. T. (2012). Heritability in cognitive performance: Evidence using computer-based testing. Journal of Genetic Psychology, 173(1), 112-118. doi:10. 1080/00221325.2011.573025

Horesh, N. (2001). Self-report vs. computerized measures of impulsivity as a correlate of suicidal behavior. Crisis, 22(1), 27-31. doi:10.1027//0227-

\subsection{2 .1 .27}

Inglis, E. A., Szymkowiak, A., Gregor, P., Newell, A. F., Hine, N., Wilson, B. A., ...Shah, P. (2004). Usable technology? Challenges in designing a memory aid with current electronic devices. Neuropsychological Rehabilitation, 14(1-2), 7787. doi:10.1080/09602010343000129

Joly, M. C. R. A., Martins, R. X., Abreu, M. C. D., Souza, P. R. R. D., \& Cozza, H. F. P. (2004). Análise da produção científica em avaliação psicológica informatizada. Avaliação Psicológica, $3(2), 121-129$

Kang, E. K., Kim, D. Y., \& Paik, N. J. (2012). Transcranial direct current stimulation of the left prefrontal cortex improves attention in patients with traumatic brain injury: A pilot study. Journal of Rehabilitation Medicine, 44(4), 346-350. doi:10.2340/16501977-0947

Kato, P. M. (2010). Video games in health care: Closing the gap. Review of General Psychology, 14(2), 113-121. doi:10.1037/a0019441

Kay, G. G., \& Starbuck, V. N. (1997). Computerized neuropsychological assessment. In M. E. Maruish \& J. A. Moses Jr. (Eds.), Clinical neuropsychology: Theoretical foundations for practitioners (pp. 143-161). Mahwah, NJ: Lawrence Erlbaum Associates.

Kellar, M., Watters, C., \& Duffy, J. (2005). Motivational factors in game play in two user groups. In Proceedings of DiGRA 2005 Conference: Changing views - Worlds in play. Vancouver, Canada: Digital Games Research Association.

Lezak, M. D. (1995). Neuropsychological assessment ( $3^{\text {rd }}$ ed.). Oxford, UK: Oxford University Press.

Luciana, M. (2003). Practitioner review: Computerized assessment of neuropsychological function in children: Clinical and research applications of the Cambridge Neuropsychological Testing Automated Battery (CANTAB). Journal of Child Psychology and Psychiatry, 44(5), 649-663. doi:10.1111/1469-7610.00152

Lufi, D., \& Fichman, N. (2012). Development and use of a computerized test, MATH-CPT, to assess attention. Percept Mot Skills, 114(1), 59-74. doi:10.2466/08.11.22.PMS.114.1.59-74

Ma, H. I., Hwang, W. J., Fang, J. J., Kuo, J. K., Wang, C. Y., Leong, I. F., \& Wang, T. Y. (2011). Ef- 
fects of virtual reality training on functional reaching movements in people with Parkinson's disease: A randomized controlled pilot trial. Clinical Rehabilitation, 25(10), 892-902. doi:10.1177/0269215511406757

Mattos, P. (1998). Uso de testes computadorizados em Neuropsicologia. In R. J. Gagliardi \& R. Reimao (Eds.), Clínica neurológica (pp. 319-322). São Paulo, SP: Lemos.

McLellan, D. L. (1991). Functional recovery and the principles of disability medicine. In M. Swash \& J. Oxbury (Eds.), Clinical neurology (pp. 768790). Edinburgh, UK: Churchill Living-Stone.

Miller, D. I., Talbot, V., Gagnon, M., \& Messier, C. (2013). Administration of neuropsychological tests using interactive voice response technology in the elderly: Validation and limitations. Frontiers in Neurology, 4, 107. doi:10.3389/ fneur.2013.00107

Miller, E. N. (1996). CalCAP: California Computerized Assessment Package (manual). Version Revision 4.1. Los Angeles, CA: Norland Software.

Miller, E. N., Satz, P., \& Visscher, B. (1991). Computerized and conventional neuropsychological assessment of HIV-1 infected homosexual men. Neurology, 41, 1608-1616.

Nouchi, R., Taki, Y., Takeuchi, H., Hashizume, H., Akitsuki, Y., Shigemune, Y., ...Kawashima, R. (2012). Brain training game improves executive functions and processing speed in the elderly: A randomized controlled trial. PloS one, 7(1), e29676. doi:10.1371/journal.pone.0029676

Ott, B. R., Festa, E. K., Amick, M. M., Grace, J., Davis, J. D., \& Heindel, W. C. (2008). Computerized maze navigation and on-road performance by drivers with dementia. Journal of $\mathrm{Ge}$ riatric Psychiatry and Neurology, 21(1), 18-25. doi:10.1177/0891988707311031

Overton, E. T., Kauwe, J. S., Paul, R., Tashima, K., Tate, D. F., Patel, P., ...Clifford, D. B. (2011). Performances on the CogState and standard neuropsychological batteries among HIV patients without dementia. AIDS and Behavior, 15(8), 1902-1909. doi:10.1007/s10461-011-0033-9

Parsons, S., \& Cobb, S. (2011). State-of-the-art of Virtual Reality technologies for children on the autism spectrum. European Journal of Special Needs Education, 26(3), 355-366. doi:10.1080/ 08856257.2011 .593831
Pérez-Salas, C. P. (2008). Realidad virtual: un aporte real para la evaluación y el tratamiento de personas con discapacidad intelectual. Terapia Psicológica, 26(2), 253-262.

Pietrzak, R., Maruff, P., Mayes, L., Roman, S. A., Sosa, J. A., \& Snyder, J. C. (2008). An examination of the construct validity and factor structure of the Groton Maze Learning Test, a new measure of spatial working memory, learning efficiency, and error monitoring. Archives of Clinical Neuropsychology, 23, 433-445. doi:10.1016/j.acn.2008.03.002

Pollak, Y., Weiss, P. L., Rizzo, A. A., Weizer, M., Shriki, L., Shalev, R. S., \& Gross-Tsur, V. (2009). The utility of a continuous performance test embedded in virtual reality in measuring ADHD-related deficits. Journal of Developmental \& Behavioral Pediatrics, 30(1), 2-6. doi:10.1097/DBP.0b013e3181969b22

Powell, D. H., Kaplan, E. F., Whitla, D., Catlin, R., \& Funkenstein, H. H. (1993). Microcog: Assessment of cognitive functioning (Version 2.1) [Computer software]. San Antonio, TX: The Psychological Corporation.

Prigatano, G. P. (1986). Neuropsychological rehabilitation after brain injury. Baltimore, MD: Johns Hopkins University Press.

Prigatano, G. P. (1997). Learning from our successes and failures: Reflections and comments on "cognitive rehabilitation: How it is and how it might be". Journal of the International Neuropsychological Society, 3(05), 497-499.

Pugnetti, L., Mendozzi, L., Attree, E. A., Barbieri, E., Brooks, B. M., Cazzullo, C. L., ...Rose, F. D. (1998). Probing memory and executive functions with virtual reality: Past and present studies. CyberPsychology and Behavior, 1(2), 151162.

Reeves, D., Winter, K. P., Bleiberg, J., \& Kane, R. L. (2007). ANAM $₫$ Genogram: Historical perspectives, description, and current endeavors. Archives of Clinical Neuropsychology, 22(Suppl. 1), S15-S37 doi:10.1016/j.acn.2006.10.013

Ritsner, M. S., Blumenkrantz, H., Dubinsky, T., \& Dwolatzky, T. (2006). The detection of neurocognitive decline in schizophrenia using the Mindstreams. Schizophrenia Research, 82(1), 39-49. doi:10.1016/j.schres.2005.10.014 
Rivero, T. S., Querino, E. H., \& Starling-Alves, I. (2012). Videogame: Seu impacto na atenção, percepção e funções executivas. Revista Neuropsicologia Latinoamericana, 4(2), 38-47.

Rizzo, A. A., Buckwalter, J. G., Bowerly, T., Van Der Zaag, C., Humphrey, L., Neumann, U., ...Sisemore, D. (2000). The virtual classroom: A virtual reality environment for the assessment and rehabilitation of attention deficits. CyberPsychology \& Behavior, 3(3), 483-499.

Rohlman, D. S., Villanueva-Uy, E., Ramos, E. A. M., Mateo, P. C., Bielawski, D. M., Chiodo, L. M., ...Ostrea, E. M., Jr. (2008). Adaptation of the Behavioral Assessment and Research System (BARS) for evaluating neurobehavioral performance in Filipino children. NeuroToxicology, 29, 143-151.

Rose, F. D., Brooks, B. M., \& Rizzo, A. A. (2005). Virtual reality in brain damage rehabilitation: Review. CyberPsychology \& Behavior, 8(3), 241-262. doi:10.1089/cpb.2005.8.241

Rufo-Campos, M. (2006). La neuropsicología: historia, conceptos básicos y aplicaciones. Revista de Neurología, 43(Supl. 1), S57-S58.

Sahakian, B. J., \& Owen, A. M. (1992). Computerized assessment in neuropsychiatry using CANTAB: Discussion paper. Journal of the Royal Society of Medicine, 85, 399-402.

Schatz, A. M., Ballantyne, A. O., \& Trauner, D. A. (2001). Sensitivity and specificity of a Computerized Test of Attention in the diagnosis of attentiondeficit/hyperactivity disorder. Assessment, 8(4), 357-365. doi:10.1177/107319110100800401

Schatz, P., \& Browndyke, J. (2002) Applications of computer-based neuropsychological assessment. Journal of Head Trauma Rehabilitation, $17(5), 395-410$

Simpson, P. M., Surmon, D. J., Wesnes, K. A., \& Wilcock, G. K. (1991). The cognitive drug research computerized assessment system for demented patients: A validation study. International Journal of Geriatric Psychiatry, 6(2), 95-102.

Soekadar, S. R., Birbaumer, N., \& Cohen, L. G. (2011). Brain-computer interfaces in the rehabilitation of stroke and neurotrauma. Systems Neuroscience and Rehabilitation, 3-18.

Sohlberg, M. M., \& Mateer, C. A. (1989). Introduction to cognitive rehabilitation: Theory and practice. New York: Guilford Press.
Soto-Pérez, F., Martín, F., Angel, M., \& Jiménez Gómez, F. (2010). Tecnologías y neuropsicología: hacia una ciber-neuropsicología. Cuadernos de Neuropsicología, 4(2), 112-131.

Stuifbergen, A. K., Becker, H., Perez, F., Morison, J., Kullberg, V., \& Todd, A. (2012). A randomized controlled trial of a cognitive rehabilitation intervention for persons with multiple sclerosis. Clinical Rehabilitation, 26(10), 882-893. doi:10.1177/0269215511434997

Svoboda, E., \& Richards, B. (2009). Compensating for anterograde amnesia: A new training method that capitalizes on emerging smartphone technologies. Journal of the International Neuropsychological Society, 15(4), 629-638. doi:10.1017/ S1355617709090791

Tanaka, J. W., Wolf, J. M., Klaiman, C., Koenig, K., Cockburn, J., Herlihy, L., ...Schultz, R. T. (2010). Using computerized games to teach face recognition skills to children with autism spectrum disorder: The Let's Face It! program. Journal of Child Psychology and Psychiatry, 51(8), 944-952. doi:10.1111/j.14697610.2010.02258.x

Tanaka, J. W., Wolf, J. M., Klaiman, C., Koenig, K., Cockburn, J., Herlihy, L., ...Schultz, R. T. (2012). The perception and identification of facial emotions in individuals with autism spectrum disorders using the Let's Face It! Emotion Skills Battery. Journal of Child Psychology and Psychiatry, 53(12), 1259-1267. doi:10.1111/ j.1469-7610.2012.02571.x

Tornatore, J. B., Hill, E., Laboff, J. A., \& McGann, M. E. (2005). Self-administered screening for mild cognitive impairment: Initial validation of a computerized test battery. The Journal of Neuropsychiatry and Clinical Neurosciences, 17(1), 98. doi:10.1176/appi.neuropsych.17.1.98

Weintraub, S. (2000). Neuropsychological assessment of mental state. In M. M. Mesulam (Ed.), Principles of behavioral and cognitive neurology ( $2^{\text {nd }}$ ed., pp. 121-173). New York: Oxford University Press.

Wild, K., Howieson, D., Webbe, F., Seelye, A., \& Kaye, J. (2008). Status of computerized cognitive testing in aging: A systematic review. Alzheimer's \& Dementia, 4, 428-437. doi:10.1016/j.jalz.2008.07.003 
Williams, L. M., Whitford, T. J., Flynn, G., Wong, W., Liddell, B. J., Silverstein, S., ...Gordon, E. G. (2008). General and social cognition in first episode schizophrenia: Identification of separable factors and prediction of functional outcome using the IntegNeuro test battery. Schizophrenia Research, 99, 182-191.

Wilson, B. A. (1996). Reabilitação das deficiências cognitivas. In R. Nitrini, P. Caramelli, \& L. L. Mansur, Neuropsicologia: Das bases anatômicas à reabilitação (pp. 314-343). São Paulo, SP: Clínica Neurológica, Hospital de Clínicas, Universidade de São Paulo.

Wilson, B. A., Evans, J. J., Emslie, H. C., \& Malinek, V. (1997). Evaluation of NeuroPage: A new memory aid. Journal of Neurology, Neurosurgery and Psychiatry, 63, 113-115. doi:10.1136/ jnnp.63.1.113
Woo, H. (2008). Computerized neuropsychological assessments. CNS Spectrums, 13(10, Suppl. 16), 14-17. doi:10.1080/13854046.2012.663001

World Health Organization. (1980). International classification of impairments, disabilities and handicaps: A manual of classification relating to the consequences of disease. Geneva, Switzerland: Author.

Zangwill, O. L. (1947). Psychological aspects of rehabilitation in cases of brain injury. British Journal of Psychology, 37, 60-69.

Received: April, 15, 2013

$1^{\text {st }}$ revision: September, 17, 2013

$2^{\text {nd }}$ revision: January, 27, 2014

Accepted: February, 14, 2014 